\begin{tabular}{|c|c|c|}
\hline \multirow{2}{*}{\multicolumn{2}{|c|}{$\begin{array}{l}\text { DE } \\
\\
\text { OPE GRUYTER }\end{array}$}} & ECONOMIC THEMES (2016) 54(1): 61-82 \\
\hline & & DOI 10.1515/ethemes-2016-0004 \\
\hline
\end{tabular}

\title{
DETERMINANTS OF THE LEVEL OF CONTRIBUTIONS FOR PENSION AND DISABILITY INSURANCE: THE EU AND SERBIA
}

\author{
Milena Nikolić \\ PhD student, University of Niš, Faculty of Economics, Serbia \\ $\bowtie$ milenanikolic1983@yahoo.com \\ Biljana Rakić \\ University of Niš, Faculty of Economics, Serbia \\ 凶iljana.rakic@eknfak.ni.ac.rs
}

UDC

364.35

(4-672EU

$+497.11)$

Review paper

Received:

27.07.2015

Accepted:

05.04.2016

\begin{abstract}
Both in theory and practice, great attention is paid to the analysis of the pension expenditures level, their determinants, as well as the options for their reduction, whereas the analysis of the revenues level and contributions, as the most significant revenue in contribution-based pension systems, is often neglected. The aim of this paper is to analyse the determinants of the level of contributions for pension and disability insurance in order to identify options for increasing their levels in the pension system of the Republic of Serbia. By using the comparative method, a comparative analysis of data about the trends of the most significant determinants of contribution levels among the European Union Member States and Serbia is performed. Research results have shown that increase in the contribution level for pension and disability insurance in the Republic of Serbia can be achieved by extending the definition of contribution base of employees, increasing the average effective retirement age and increasing the effective population coverage by this insurance. In addition to pointing out the options for increasing the contribution level for pension and disability insurance, the authors also propose the measures which can be applied in order to affect the increase of the contribution level for this insurance and, therefore, the total revenues level of the pension system of the Republic of Serbia.
\end{abstract}

Key words: pension system, pension and disability insurance, determinants of the level of contributions, the European Union, Serbia

JEL classification: H55, G22, J26

This paper is realised within the projects no. 179066 and 42006, financed by the Ministry of Education, Science and Technological Development. 


\section{Introduction}

Financial balance in pension systems, which are based on a pay as you go system for pension financing, has been disrupted in many European countries. These countries are facing deficits in the funds for pension payments, which seriously threatens their stability. At times when a drastic increase in expenditures for pensions is expected, due to population aging and retirement of the baby boom generations, the chances for these deficits to continue increasing are great, which can threaten public finances of many countries.

Great efforts are made, both at the national level and the European Union, to identify determinants of the level of expenditures for pension and disability insurance and the options for their decrease. However, this is not the case with revenues for pension and disability insurance. In order to solve the deficit problem, the methods for financing these expenditures must be considered. Primarily, this refers to identifying determinants which determine the level of collected contributions, considering the fact that in countries where pension systems are based on contribution payments, these revenues are the most significant. For this purpose, the paper analyses contributions for pension and disability insurance and determinants which affect their levels; they are analysed among European Union Member States and Serbia and the existing options for increasing the total amount of these contributions are pointed out.

At the beginning of this paper, the most significant determinants of the level of contributions for pension and disability insurance are identified contribution base and rates, duration of work life, population coverage by this insurance and it is pointed out how they can affect the increase of contribution levels. Then, a comparative analysis of these determinants is performed in Europe and Serbia and the options for increasing the levels of contributions for pension and disability insurance in Serbia are identified. Finally, the significance of efficient collection and enforcement of contribution is pointed out, with the aim of completing the analysis of determinants of contribution levels and to determine all available options for increasing the levels of the collected contributions for pension and disability insurance.

\section{Determining the Most Significant Determinants of Contribution Levels for Pension and Disability Insurance}

To manage finances of the pension system successfully, it is necessary to determine the options for increasing the levels of the collected contributions for pension and disability insurance. In order to identify them, it is necessary to determine what affects their levels, that is to identify the determinants of contribution levels. The most significant determinants of contribution levels are:

1. contribution base, 
2. contribution rate,

3. duration of work life,

4. population coverage.

The possibilities of influence of all of these determinants of the contribution levels are various. This part of the paper analyses in detail each of them, in order to determine in which way they can influence the increase of contributions for pension and disability insurance.

\subsection{Contribution Base and Contribution Rate for Pension and Disability Insurance}

Contribution base and rate represent two most important parameters in the pension system of every country because by applying the contribution rate on the base, the amount of contribution to be paid is determined. Since they represent important determinants of the contribution level for pension and disability insurance, it is necessary to analyse each one of them separately and determine the options for increasing the levels of these contributions.

The level of contribution for pension and disability insurance can be affected by the definition of the contribution base and regulations about the minimum and maximum contribution base. The contribution base is usually defined as reference salary, which is used for the calculation of contribution (OECD, 2005, p. 41). This definition mainly refers to the employees, because their base is earnings, that is the salary, whereas for the insured who are selfemployed and in agriculture, it is different because the contribution base is represented by income which are realised on the basis of performing those activities. Depending on how the contribution base is defined, the level of contribution for pension and disability insurance changes for each of the mentioned category of the insured.

Determining the minimum contribution base, that is the lowest earnings for which contribution is paid, is performed with the aim of releasing the employees who have very low earnings or who work part-time from the obligation to pay contributions and for the maximum contribution base, not to pay for the highest earnings contributions for pension and disability insurance, since the pension systems cannot provide sufficiently high benefits for the insured (Cichon et al., 2004, pp. 270-271). By reducing the minimum and increasing the maximum contribution base for pension calculation, the contribution base increases (Cichon et al., 2004, p. 272), which causes an increase of the level of contribution for pension and disability insurance.

The contribution rate for pension and disability insurance is a determinant which determines which part of the earnings will be taken for pension and disability insurance (Pallares-Miralles et al., 2012, p. 44). Determining its level 
should be performed in such a manner to enable the collection of contribution funds which will provide adequate pension benefits to pension beneficiaries at old age and to cover the costs of pension system functioning. The impact on the total amount of funds for pension and disability insurance by contribution rate is performed by changing its level, because increasing the contribution rate affects the increase of contribution funds and vice versa. However, this is not always the case. Namely, only increasing the contribution rate, without taking into consideration economic capacities of the employees and the employers, may lead to opposite consequences. Excessively high contribution rates may discourage employers to employ workers and employees to work, as well as influence the employees to look for a job in an informal sector (Demarco \& Rofman, 1999, p. 4), which can affect the increase of contribution evasion. This is the reason why the decision about its change must be made with great caution.

\subsection{Duration of Work Life and its Impact on the Level of Contribution for Pension and Disability Insurance}

The level of contribution for pension and disability insurance can be increased by increasing the duration of work life, that is the average length of service. The insured who have longer duration of work life, the period of contribution payments for pension and disability insurance is longer, which enables the increase of the level of paid contributions in the pension system. Therefore, the greater the number of the insured with a longer duration of work life, the greater is the total amount of contributions for these purposes.

Figure 1 Duration of work life

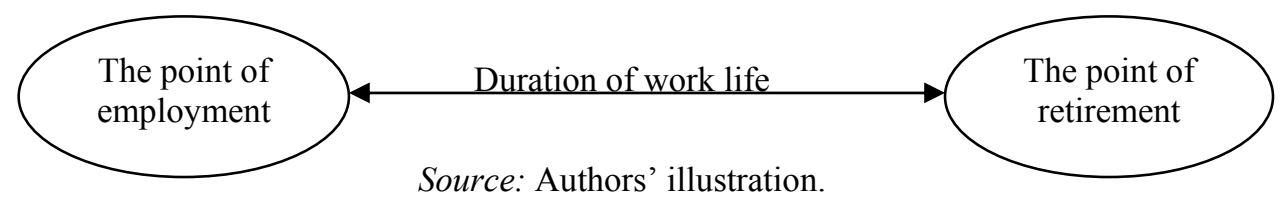

Duration of work life is greatly affected by the point of employment, that is the point of entering employment and the point of retirement, that is the retirement age (Figure 1). It has been recognized that in the recent decades, young people enter the labour market at a later age, due to the longer duration of the education process, but also due to the inability to find a job. On the other hand, earlier retirement is present more often, which is mainly the consequence of the relaxed conditions for retirement and liberalised conditions for the calculation of the pension (Pošarac, 1995, pp. 77-85; Rakić \& Ivković, 2010, pp. 52-53). Due to massive early retirement, the duration of work life has been significantly shortened in the second half of the twentieth century, which also influenced the decrease of the levels of paid contributions in the pension systems. 
The pension policy cannot influence the point of employment, but it can influence the point of retirement. By taking measures, such as increasing the retirement age, abolition of early retirement, introducing reductions for early retirement and making the criteria for disability retirement more strict, and by doing so, increasing duration of work life and the level of contributions for pension and disability insurance.

\subsection{Population Coverage by Pension and Disability Insurance}

Population coverage can be considered in two ways - as a legal coverage or effective (actual) coverage. Legal coverage is a broader category than the effective (actual) coverage, because it shows which persons are by law or regulation, participants in the plans of social insurance and they have an obligation of paying contributions for these plans (McGillivrey, 2001, p. 4), while a narrower definition is effective (actual) coverage because it includes the active insured, the ones who actually participate in these plans (ILO, 2014, pp. 165-166).

Determining the legal and effective social security coverage of population is very complex. This is a multi-dimensional concept, so it is necessary to take into consideration at least three dimensions when determining them (Cichon et al., 2004, pp. 452-453; ILO, 2014, p. 165):

1. Scope - the number and the types of risks and needs for which the population of a country is insured (eg. old age, disability, unemployment, illness, health, maternity, etc.);

2. Extent - population percentage which is covered by this insurance in relation to the total population, that is within its target group (certain gender, age,etc.);

3. Level - the level of social insurance, which is realised (eg. absolute or relative level of benefits, the replacement rate, the poverty line, etc.).

No matter which dimension is in question, it is important to make a difference between the legal and the effective (actual) coverage of population by a certain type of insurance. While the legal coverage indicates the number and types of areas of social insurance which are provided access by law, the population percentage or labour force, which by legal regulations may also cover the level of benefits, which can be realised according to the law, the actual, that is the effective one, indicates the number and types of areas which the population has actually accessed, the percentage of population which is actually covered and the level of benefits which is realised (ILO, 2014, pp. 165166). Therefore, the effective (actual) coverage viewed according to all dimensions is, for the most part, lower than the legal one, due to numerous problems which arise in law enforcement (ILO, 2014, pp. 165-166).

The same dimensions for determining the coverage by social insurance can be applied in the area of pension and disability insurance. Thus, it is also possible to determine for which risks the population is insured in this type of 
insurance (eg. old age, disability), then the percentage of the population covered by the plans of pension and disability insurance and the adequacy of the benefits. Since greater effective (actual) coverage of the population by pension and disability insurance enables the collection of a greater amount of contributions for this insurance, analysing this coverage of population is significant for the improvement of the process of contribution collection.

\section{Comparative Analysis of the Determinants of the Levels of Contribution for Pension and Disability Insurance in the European Union and Serbia}

After determining the options for influencing the level of contribution for pension and disability insurance, the determinants of the levels of contributions among different countries must be analysed, in order to determine the possibilities for increasing contributions in a certain country. Having in mind the fact that Serbia has a tendency of becoming a Member State of the European Union, this part of the paper analyses the determinants of the level of contributions for pension and disability insurance for the Member States of the EU and Serbia, with the aim of determining the options for increasing the level of contribution in Serbia.

\subsection{Analysis of the Contribution Base and Rate for Pension and Disability Insurance}

There are various definitions of the contribution base in the European Union. For employees, it is mainly gross wage, but in some countries besides gross wage, bonuses, stimulations, overtime payments (Poland), holiday bonuses (Croatia and Slovenia) are also included, so that it significantly increases the value of the contribution base (Fultz \& Stanovnik, 2004, p. 42). For the self-employed, the contribution base is represented by the income which is realised by performing the activities, the declared, assessed or taxable income (Slovenia, Czech Republic, Hungary, Poland, Sweden), and for farmers the cadastral income per household member which exceeds minimum wage (Slovenia) or a certain percent of an average wage (Croatia) (SSA \& ISSA, 2014, pp. 74, 134, 232, 277, 292; Fultz \& Stanovnik, 2004, pp. 43-44). According to the Law on Compulsory Social Insurance Contributions (Official Gazette RS, 84/2004, Articles 13, 16, 22) and the Law on Amendments and Supplements to the Law on Compulsory Social Insurance Contributions (Official Gazette RS, 47/2013, Articles 3, 6), the contribution base in Serbia for the employees is the salary or the income compensation, for the self-employed it is taxable income, lump sum income, taxable profit, contracted compensation or monthly amount of personal income, and for farmers it is the taxable profit or the monthly amount of personal income (if the income taxpayers are self-employed), that is the lowest monthly base. 
The differences among European Union Member States are also evident in defining the minimum and the maximum contribution base. The minimum monthly contribution base in Finland, Germany and Spain is determined in nominal amount; in Hungary, Lithuania, Luxembourg and Slovenia as minimum monthly wage and in Greece, Poland, Romania and Slovakia it is not determined (SSA \& ISSA, 2014). After the passing of the Law on Amendments and Supplements to the Law on Compulsory Social Insurance Contributions (Official Gazette RS, 62/2006, Article 5) in 2006, the minimum monthly contribution base in Serbia is determined as $35 \%$ of the average monthly salary paid in the previous quarter. The maximum monthly contribution base for EU-27 Member States where population earnings are high (Austria, Belgium, Germany, Sweden, the United Kingdom) is determined at the value of 1-1.5 average earnings, and in those states where population earnings are lower (Italy, Greece, Poland, Slovakia) it is determined at the value of 2.5-5 average earnings (OECD, 2013, p. 125). This contribution base is very high in Serbia as well since, as it is in Slovakia, it is determined at the value of 5 average monthly salaries (Republic fund for pension and disability insurance). Among the considered states, there are those where the maximum base for contribution calculation is not determined (Estonia, Finland, Hungary and Romania) (SSA \& ISSA, 2014).

Comparative analysis of the contribution base for pension and disability insurance indicates that there are options for extending the contribution base in the definition itself, for the employees, where this base can include holiday bonuses, bonuses etc. When determining minimum and the maximum monthly contribution base, it is evident that there are no possibilities for increasing the contribution for pension and disability insurance in Serbia, because the minimum monthly salary is lower than it would be if it was determined as the minimum monthly salary, and the maximum monthly contribution base is already high enough in relation to EU-27 Member States.

Analysis of the contribution rate among members is performed by comparison of its level from 2002 to 2014. During this period, they increased in 10 Member States of EU (Table 1). The most significant increase was noted in Hungary 9.50, France 8.30 and Sweden 5.52 percentage points, while in others it was lower - Latvia 3.23, Cyprus 3.00, Finland 2.20, the Czech Republic and Estonia 2.00 and Lithuania 1.30 percentage points.

In some states in the observed period, the contribution rate decreased. The most significant decrease was noted in Bulgaria 13.20, Ireland 8.50, Poland 5.00, the Netherlands 3.85 and Romania 3.70 percentage points. Among the reported states, it can also be seen that there are those which contribution rates remained the same. This was the case in Austria, Belgium, Greece, Luxembourg, Malta, Portugal, Slovenia and Spain. 
Extremely high contribution rates in 2014 were noted in Hungary $35.50 \%$, Portugal $34.75 \%$, Latvia $34.09 \%$, Italy $33.00 \%$, Romania $31.30 \%$, while the lowest were in Ireland $8.25 \%$, Cyprus $15.60 \%$, Luxembourg $16.00 \%$, Belgium $16.36 \%$, Bulgaria $17.80 \%$ and Germany $18.90 \%$. Identical contribution rates for the employees and the employers were noted in Cyprus, Germany, Luxembourg and Malta.

Table 1 Contribution rates in public pension systems in EU-27 (in \%)

\begin{tabular}{|l|c|c|c|c|c|c||}
\hline \multirow{2}{*}{ Country } & \multicolumn{3}{|c|}{$\mathbf{2 0 0 2}$} & \multicolumn{3}{c|}{$\mathbf{2 0 1 4}$} \\
\cline { 2 - 7 } & $\mathbf{E e}$ & $\mathbf{E r}$ & $\mathbf{T}$ & $\mathbf{E e}$ & $\mathbf{E r}$ & $\mathbf{T}$ \\
\hline Austria & 10.25 & 12.55 & 22.80 & 10.25 & 12.55 & 22.80 \\
\hline Belgium & 7.50 & 8.86 & 16.36 & 7.50 & 8.86 & 16.36 \\
\hline Bulgaria & 22.25 & 8.75 & 31.00 & 7.90 & 9.90 & 17.80 \\
\hline Czech Rep. & 6.50 & 19.50 & 26.00 & 6.50 & 21.50 & 28.00 \\
\hline Cyprus & 6.30 & 6.30 & 12.60 & 7.80 & 7.80 & 15.60 \\
\hline Denmark & - & - & - & - & - & - \\
\hline Estonia & 0 & 20.00 & 20.00 & 2.00 & 20.00 & 22.00 \\
\hline Finland & 4.40 & 16.70 & 21.10 & 5.55 & 17.75 & 23.30 \\
\hline France & 6.65 & 9.80 & 16.45 & 10.05 & 14.70 & 24.75 \\
\hline Germany & 9.55 & 9.55 & 19.10 & 9.45 & 9.45 & 18.90 \\
\hline Greece & 6.67 & 13.33 & 20.00 & 6.67 & 13.33 & 20.00 \\
\hline Hungary & 8.00 & 18.00 & 26.00 & 8.50 & 27.00 & 35.50 \\
\hline Ireland & 6.00 & 10.75 & 16.75 & 4.00 & 4.25 & 8.25 \\
\hline Italy & 8.89 & 23.81 & 32.7 & 9.19 & 23.81 & 33.00 \\
\hline Latvia & - & - & 30.86 & 10.50 & 23.59 & 34.09 \\
\hline Lithuania & 2.50 & 22.50 & 25.00 & 3.00 & 23.30 & 26.30 \\
\hline Luxembourg & 8.00 & 8.00 & 16.00 & 8.00 & 8.00 & 16.00 \\
\hline Malta & 10.00 & 10.00 & 20.00 & 10.00 & 10.00 & 20.00 \\
\hline Netherlands & 19.15 & 8.90 & 28.05 & 18.50 & 5.70 & 24.20 \\
\hline Poland & 16.26 & 16.26 & 32.52 & 11.26 & 16.26 & 27.52 \\
\hline Portugal & 11.00 & 23.75 & 34.75 & 11.00 & 23.75 & 34.75 \\
\hline Romania & 11.66 & 23.34 & 35.00 & 10.50 & 20.80 & 31.30 \\
\hline Slovakia & 6.40 & 21.60 & 28.00 & 7.00 & 20.00 & 27.00 \\
\hline Slovenia & 15.50 & 8.85 & 24.35 & 15.50 & 8.85 & 24.35 \\
\hline Spain & 4.70 & 23.60 & 28.30 & 4.70 & 23.60 & 28.30 \\
\hline Sweden & 7.00 & 10.21 & 17.21 & 7.00 & 15.73 & 22.73 \\
\hline U. Kingdom & 10.00 & 11.90 & 21.90 & 9.05 & 11.90 & 20.95 \\
\hline
\end{tabular}

Source: SSA \& ISSA, 2002, pp. 22-23; SSA \& ISSA, 2014, pp. 23-28. Note: Ee-employees, Er-employer, T-total.

In the observed period, changes in the contribution rate were made in Serbia as well. It first decreased in 2001 from $32 \%$ to $19.6 \%$, and after that increased on several times (Petraković, 2007, pp. 37-38). The first increase was made in 2003 to $20.6 \%$ (The national agency for local economic development), and the second in 2004 by the Law on compulsory social insurance contributions (Official Gazette RS, 84/2004, Article 44), when the contribution rate was 
determined at $22 \%$, whereby the burden of contribution payment was equally allocated among the employees and the employers. After this increase, the contribution rate did not change up to 2013, when by the Law on Amendments and Supplements to the Law on Compulsory Social Insurance Contributions (Official Gazette RS 47/2013, Article 7) it increased to 24\%, and in a way that the part paid by the employees increased from $11 \%$ to $13 \%$. The last increase of the contribution rate in Serbia was made in 2014 by the Law on Amendments and Supplements to the Law on Compulsory Social Insurance Contributions (Official Gazette RS, 57/2014, Article 1), when it increased to $26 \%$, that is $14 \%$ for the employees and $12 \%$ for employers.

Comparative analysis of the level of the contribution rate for pension and disability insurance in Serbia and EU-27 Member States, it was found that there are 10 Member States where the contribution rate for pension and disability insurance is higher than the one which is applied in Serbia, and that only in a few of these states it is significantly higher. In comparison to Croatia and Slovenia, the contribution rate in Serbia is higher by 6 and 1.65 percentage points, respectively (SSA \& ISSA, 2014, pp. 23-28). Increase of the contribution rate in Serbia in conditions when there is high unemployment is the reflection of a very serious financial situation in its pension system. Nevertheless, the question which arises is whether the decision about this increase was right. From the financial aspect, the increase was necessary, but due to the mentioned circumstances in the economy and a high evasion of contribution for pension and disability insurance, there is a greater possibility that it will not significantly influence the increase of the level of contribution.

Significant changes of contribution rates for pension and disability insurance can be expected in a great number of Member States, since in the future period baby boom generations are supposed to retire, and as a consequence, a significant increase of pension expenditures (Rakić \& Nikolić, 2011, p. 406). When making a decision about its change, the creators of the pension policy must consider all the positive and negative consequences and take into account all the relevant circumstances and possibilities in a specific country.

\subsection{Analysis of Duration of Work Life}

Unlike the last decades of the $20^{\text {th }}$ century, when duration of work life was decreasing, since the beginning of the $21^{\text {st }}$ century, it has started increasing. In EU27, from 2000 to 2013, it increased from 32.9 to 35.2 years (Table 2). The increase was noted in all Member States, except in Romania, where there was a decrease of 4 years. The most significant increase of duration of work life was realised in the Netherlands 4.3, Sweden 4.1 and Spain 4.0, and the smallest in Greece 0.4, Lithuania 0.5, Denmark 0.6, Finland and Slovakia 0.8 and Portugal 0.9 years. 
The longest duration of work life for the observed period was noted by the insured of Sweden, Denmark, the Netherlands, the United Kingdom, Finland and Germany. During this period, there was an increase in duration of work life from 34.3-38.3 years to 37.2-40.9 years. The shortest duration of work life was noted in Hungary, Italy, Bulgaria and Malta. At the turn of the $21^{\text {st }}$ century, it was in the range of 27.5-29.0 years, and in 2013 from 30.3-32.5 years. Despite the increase in the duration of work life in these states for the observed period, there is still a very short duration of work life.

Table 2 Duration of work life in EU-27

\begin{tabular}{|l|c|c|c|c|c|c|c|c|c||}
\hline \multirow{2}{*}{ Country } & \multicolumn{3}{|c|}{$\mathbf{2 0 0 0}$} & \multicolumn{3}{|c|}{$\mathbf{2 0 1 0}$} & \multicolumn{3}{|c|}{$\mathbf{2 0 1 3}$} \\
\cline { 2 - 11 } & $\mathbf{M}$ & $\mathbf{W}$ & $\mathbf{T}$ & $\mathbf{M}$ & $\mathbf{W}$ & $\mathbf{T}$ & $\mathbf{M}$ & $\mathbf{W}$ & $\mathbf{T}$ \\
\hline Austria & 37.2 & 29.7 & 33.5 & 38.5 & 33.4 & 36.3 & 39.0 & 34.3 & 37.0 \\
\hline Belgium & 33.8 & 26.4 & 30.2 & 35.0 & 29.9 & 32.5 & 34.8 & 30.0 & 32.4 \\
\hline Bulgaria & 31.0 & 26.9 & 29.0 & 33.1 & 29.9 & 31.5 & 33.2 & 30.7 & 32.0 \\
\hline Czech Rep. & 36.7 & 30.3 & 33.6 & 37.3 & 30.4 & 33.9 & 37.8 & 31.5 & 34.7 \\
\hline Cyprus & 40.1 & 27.9 & 34.1 & 40.7 & 33.1 & 36.9 & 40.0 & 32.5 & 36.2 \\
\hline Denmark & 40.2 & 36.3 & 38.3 & 41.0 & 37.8 & 39.4 & 40.3 & 37.6 & 38.9 \\
\hline Estonia & 34.1 & 32.6 & 33.4 & 36.1 & 35.5 & 35.8 & 37.2 & 35.8 & 36.2 \\
\hline Finland & 37.3 & 35.5 & 36.4 & 37.5 & 36.2 & 36.8 & 37.8 & 36.6 & 37.2 \\
\hline France & 34.4 & 29.2 & 31.9 & 36.0 & 32.2 & 34.1 & 36.5 & 32.8 & 34.7 \\
\hline Germany & 37.7 & 30.8 & 34.3 & 39.4 & 34.1 & 36.8 & 40.2 & 35.4 & 37.8 \\
\hline Greece & 37.8 & 24.7 & 31.6 & 36.9 & 27.4 & 32.3 & 36.1 & 27.9 & 32.0 \\
\hline Hungary & 30.3 & 24.7 & 27.5 & 31.2 & 27.1 & 29.3 & 33.1 & 28.4 & 30.8 \\
\hline Ireland & 39.4 & 26.6 & 33.2 & 38.2 & 30.0 & 34.3 & 38.4 & 30.6 & 34.5 \\
\hline Italy & 34.8 & 21.9 & 28.5 & 34.8 & 24.2 & 29.7 & 35.0 & 25.4 & 30.3 \\
\hline Latvia & 32.8 & 30.6 & 31.7 & 34.5 & 34.5 & 34.5 & 35.1 & 34.5 & 34.8 \\
\hline Lithuania & 33.9 & 33.4 & 33.6 & 32.8 & 33.4 & 33.1 & 34.1 & 34.1 & 34.1 \\
\hline Luxembourg & 34.3 & 23.7 & 29.2 & 35.2 & 28.1 & 31.6 & 36.0 & 29.2 & 32.6 \\
\hline Malta & 39.4 & 17.4 & 28.8 & 38.7 & 21.6 & 30.3 & 39.5 & 25.0 & 32.5 \\
\hline Netherlands & 39.6 & 31.2 & 35.5 & 41.8 & 36.2 & 39.0 & 42.5 & 37.1 & 39.8 \\
\hline Poland & 33.3 & 28.8 & 31.1 & 34.1 & 29.0 & 31.6 & 34.8 & 29.6 & 32.2 \\
\hline Portugal & 39.0 & 32.2 & 35.7 & 38.6 & 35.1 & 36.9 & 38.4 & 34.9 & 36.6 \\
\hline Romania & 37.8 & 34.2 & 36.0 & 35.2 & 29.2 & 31.6 & 35.5 & 29.5 & 32.0 \\
\hline Slovakia & 34.8 & 29.3 & 32.1 & 35.2 & 29.5 & 32.4 & 35.8 & 30.0 & 32.9 \\
\hline Slovenia & 33.6 & 30.0 & 31.8 & 35.9 & 32.6 & 34.2 & 35.1 & 32.1 & 33.7 \\
\hline Spain & 37.0 & 24.2 & 30.8 & 37.6 & 31.1 & 34.5 & 37.2 & 32.3 & 34.8 \\
\hline Sweden & 37.9 & 35.7 & 36.8 & 41.6 & 38.4 & 40.0 & 42.1 & 39.6 & 40.9 \\
\hline U. Kingdom & 40.3 & 33.3 & 36.9 & 40.8 & 34.8 & 37.9 & 41.1 & 35.5 & 38.4 \\
\hline EU-27 & 36.4 & 29.2 & 32.9 & 37.4 & 31.7 & 34.6 & 37.8 & 32.5 & 35.2 \\
\hline & & & & & & & & & \\
\hline
\end{tabular}

Source: Eurostat, online data code: ifsi_dwl_a, accessed: June 1, 2015. Note: M-men, W-women, T-total.

The duration of work life in Serbia is also increasing. In 2010, the total duration of work life for beneficiaries of old-age pensions was 30 years, whereby for men it was 33.0 and 28.0 years for women and in 2013, the total duration of 
work life for beneficiaries of these pensions increased to 31.0 years, owing to the increase in the duration of work life for men for one year (Republic Fund for Pension and Disability Insurance, 2015, p. 28). By comparing these data with the data for the group EU-27 and Slovenia, it can be noted that the total duration of work life and the duration of work life for both genders in Serbia was significantly shorter. Nevertheless, this is not the case when compared with Croatia. In this country, the total duration of work life in 2010 was 31.2 years, that is 33.7 for men and 29.5 for women and in 2013 it was 31.0 , that is 33.2 for men and 28.9 years for women. The decrease of the duration of work life for both genders affected the decrease of the total duration of work life, so that it is now similar to the duration of work life in Serbia (Eurostat, online data code: ifsi_dwl_a). This data clearly shows that it is necessary to introduce measures which would influence the increase of duration of work life in Serbia.

Table 3 Average effective retirement age for men in EU-27

\begin{tabular}{||l|c|c|c|c|c|c||}
\hline \multicolumn{1}{|c|}{ Country } & $\mathbf{1 9 7 0}$ & $\mathbf{1 9 8 0}$ & $\mathbf{1 9 9 0}$ & $\mathbf{2 0 0 0}$ & $\mathbf{2 0 1 0}$ & $\mathbf{2 0 1 2}$ \\
\hline Austria & 66.8 & 64.8 & 62.7 & 60.3 & 59.9 & 61.9 \\
\hline Belgium & 64.1 & 61.5 & 58.5 & 58.5 & 60.6 & 59.6 \\
\hline Bulgaria & 66.5 & 62.4 & 62.4 & 58.2 & 62.9 & - \\
\hline Czech Rep. & - & - & - & 61.6 & 62.3 & 63.1 \\
\hline Cyprus & - & - & 69.4 & 63.9 & 66.5 & - \\
\hline Denmark & 68.3 & 65.5 & 65.4 & 63.4 & 64.0 & 63.4 \\
\hline Estonia & 68.1 & 65.5 & 67.3 & 61.0 & 65.0 & 63.6 \\
\hline Finland & 65.9 & 65.9 & 61.3 & 60.1 & 61.8 & 61.8 \\
\hline France & 67.6 & 63.5 & 60.0 & 58.8 & 59.4 & 59.7 \\
\hline Germany & - & - & - & 61.0 & 62.0 & 62.1 \\
\hline Greece & 67.3 & 65.9 & 63.7 & 63.2 & 61.9 & 61.9 \\
\hline Hungary & 69.3 & 65.2 & 63.2 & 58.3 & 60.3 & 60.9 \\
\hline Ireland & 73.1 & 68.2 & 64.0 & 65.2 & 63.4 & 64.6 \\
\hline Italy & 65.0 & 61.9 & 61.8 & 60.2 & 60.5 & 61.1 \\
\hline Latvia & - & - & - & 62.2 & 64.5 & - \\
\hline Lithuania & - & - & - & 61.4 & 62.4 & - \\
\hline Luxembourg & 65.3 & 60.8 & 60.3 & 59.7 & 57.8 & 57.6 \\
\hline Malta & - & - & 60.6 & 62.4 & 60.6 & - \\
\hline Netherlands & 66.6 & 63.0 & 59.7 & 60.6 & 62.9 & 63.6 \\
\hline Poland & 73.6 & 68.0 & 66.2 & 61.6 & 61.6 & 62.3 \\
\hline Portugal & 73.1 & 69.0 & 65.6 & 65.1 & 66.5 & 68.4 \\
\hline Romania & 69.1 & 65.2 & 62.9 & 66.7 & 67.4 & - \\
\hline Slovakia & - & - & - & 59.4 & 59.9 & 60.9 \\
\hline Slovenia & - & - & - & 61.1 & 61.4 & 62.9 \\
\hline Spain & 69.4 & 64.8 & 62.9 & 61.7 & 62.3 & 62.3 \\
\hline Sweden & 67.9 & 65.3 & 64.2 & 63.7 & 65.7 & 66.1 \\
\hline U.Kindgom & 67.7 & 66.0 & 62.8 & 62.4 & 64.1 & 63.7 \\
\hline EU-27 & 68.4 & 65.1 & 63.1 & 61.5 & 62.5 & - \\
\hline OECD, & & - & & & \\
\hline
\end{tabular}

Source: OECD, http://www.oecd.org/els/public-pensions/ageingandemploymentpoliciesstatisticsonaverageeffectiveageofretirement.htm, accessed: June 1, 2015. 
The impact of the pension policy on the increase of the duration of work life, on the basis of later retirement, can be monitored by analysis of the data on the average effective retirement age and the data on the legal retirement age. In order to achieve this aim, we analysed data on the average effective retirement age of men and women in EU-27 and their legal retirement age in the period from 1970 to 2012 (Tables 3 and 4).

Table 4 Average effective retirement age for women in EU-27

\begin{tabular}{||l|c|c|c|c|c|c||}
\hline \hline Country & $\mathbf{1 9 7 0}$ & $\mathbf{1 9 8 0}$ & $\mathbf{1 9 9 0}$ & $\mathbf{2 0 0 0}$ & $\mathbf{2 0 1 0}$ & $\mathbf{2 0 1 2}$ \\
\hline Austria & 64.2 & 62.6 & 60.8 & 58.9 & 57.9 & 59.4 \\
\hline Belgium & 62.7 & 59.0 & 56.1 & 57.1 & 58.9 & 58.7 \\
\hline Bulgaria & 59.5 & 55.9 & 57.6 & 54.9 & 60.5 & - \\
\hline Czech Rep. & - & - & - & 58.0 & 58.9 & 59.8 \\
\hline Cyprus & - & - & 65.1 & 62.2 & 60.1 & - \\
\hline Denmark & 66.0 & 64.3 & 61.9 & 59.8 & 61.9 & 61.9 \\
\hline Estonia & 64.0 & 60.6 & 62.1 & 59.0 & 63.2 & 62.6 \\
\hline Finland & 62.0 & 62.7 & 60.8 & 59.9 & 61.5 & 61.9 \\
\hline France & 68.2 & 64.1 & 60.0 & 58.9 & 59.7 & 60.0 \\
\hline Germany & - & - & - & 60.3 & 61.2 & 61.6 \\
\hline Greece & 64.6 & 63.0 & 60.9 & 62.7 & 60.3 & 60.3 \\
\hline Hungary & 68.2 & 61.8 & 59.0 & 55.8 & 58.9 & 59.6 \\
\hline Ireland & 74.6 & 70.0 & 63.8 & 66.0 & 63.8 & 62.6 \\
\hline Italy & 61.7 & 61.6 & 59.2 & 58.8 & 59.1 & 60.5 \\
\hline Latvia & - & - & - & 59.6 & 63.5 & - \\
\hline Lithuania & - & - & - & 58.7 & 60.5 & - \\
\hline Luxembourg & 63.2 & 64.0 & 60.1 & 60.3 & 58.6 & 59.6 \\
\hline Malta & - & - & 61.3 & 63.1 & 61.2 & - \\
\hline Netherlands & 66.7 & 64.1 & 58.8 & 58.7 & 61.4 & 62.3 \\
\hline Poland & 72.2 & 65.1 & 63.3 & 59.2 & 59.1 & 60.2 \\
\hline Portugal & 72.5 & 67.9 & 64.3 & 62.5 & 64.6 & 66.4 \\
\hline Romania & 66.1 & 62.6 & 60.7 & 63.5 & 63.8 & - \\
\hline Slovakia & - & - & - & 55.9 & 56.9 & 58.7 \\
\hline Slovenia & - & - & - & 56.2 & 58.0 & 60.6 \\
\hline Spain & 69.0 & 66.6 & 64.9 & 61.9 & 63.1 & 63.2 \\
\hline Sweden & 66.6 & 64.0 & 62.5 & 62.3 & 63.9 & 64.2 \\
\hline U.Kingdom & 65.7 & 62.6 & 60.7 & 60.9 & 61.9 & 63.2 \\
\hline EU-27 & 65.9 & 63.0 & 60.6 & 59.8 & 60.8 & - \\
\hline
\end{tabular}

Source: OECD, http://www.oecd.org/els/public-pensions/ageingandemploymentpoliciesstatisticsonaverageeffectiveageofretirement.htm, accessed: June 1, 2015.

By analysing the average effective retirement age of men and women, it was found that in the period from 1970 to 2005 , there was a declining trend, and afterwards, a slowly increasing trend of the average effective retirement age (OECD). The average effective retirement age for men in 1970 was 68.4, and in 1980 , it was 65.1 years, while for women the average was 65.9 and 63.0 years, 
respectively. It is obvious that, in the beginning of the observed period, the average effective retirement age for both men and women in this group was more than 65 years, which is, nowadays, one of the most common legal retirement age in European countries (Belgium, Denmark, Finland, Luxembourg, Slovenia, Sweden, Cyprus for women and men, and in most other countries for men) (SSA \& ISSA, 2014, pp. 21-22). Afterwards, the average effective retirement age significantly decreased so that in 2010, despite a slight increase, it was 62.5 years for men and 60.8 for women, which is significantly less than 65 years.

In 1970, the average effective retirement age of men of 65 or more was noted in as many as 18 Member States, in 2000 only in 3 countries and in 2010 in 5 countries. For women, the average effective retirement age is even more unfavourable. Thus, the average effective retirement age of women of 65 or more was determined in 10 Member States in 1970 and in 2000, only in one and in 2010 , none. This is greatly affected by the legally defined retirement age of women, which are in most states lower than 65 years, which is not the case with the legal retirement age for men.

In 2010, according to the data about the average age of new retirees in the year of retirement, men retired at the age of 61 and women at the age of 58 in Serbia (Republic fund for pension and disability insurance, 2015, p. 22). It is obvious that in Serbia, in comparison to the EU-27, men were retired 1.5 and women 2.8 years earlier. Moreover, the retirement age of both genders was almost identical to that of Slovenia.

In conditions when it is expected for baby boom generations to be retired and when public pension systems are facing higher deficits, which are affecting the increase of the budget deficit and public debt of many European states, such a trend will have a very unfavourable effect on pension systems and the whole fiscal stability of European states. Although there are countries among these states where the legal retirement age is 65 for both genders, and also those where the retirement age of men is 65 and it is gradually increasing for women, the average effective retirement age in EU-27 and in Serbia is both for men and women significantly lower in relation to this age. Therefore, measures should be undertaken to increase the average effective retirement age.

\subsection{Analysis of Population Coverage by Pension and Disability Insurance}

Analysis of population coverage by pension insurance can be performed for two categories of population - active contributors and actual beneficiaries (ILO, 2014, p. 167). Since this paper observes the determinants of the level of contributions, it is relevant to analyse the coverage of the active contributors. In accordance with this, the analysis of population coverage is performed by observing the effective participation of the total number of active contributors in 
the labour force and the working age population, for the world by regions, the European Union and Serbia (Tables 5 and 6).

Table 5 Indicators of the effective population coverage by pension insurance by regions in the world (in \%)

\begin{tabular}{||l|c|c||}
\hline \multicolumn{1}{||}{$\mid \begin{array}{c}\text { Share of active } \\
\text { contributors in the } \\
\text { labour force } \\
\text { (15+) }\end{array}$} & $\begin{array}{c}\text { Share of active } \\
\text { contributors in the } \\
\text { working age } \\
\text { population } \\
\text { (15-64) }\end{array}$ \\
\hline Region & 18.4 & 10.5 \\
\hline Africa & 8.4 & 5.9 \\
\hline Sub-Saharan Africa & 47.4 & 23.9 \\
\hline North Africa & 37.1 & 18.6 \\
\hline Middle East & 38.0 & 27.9 \\
\hline $\begin{array}{l}\text { Latin America and the } \\
\text { Caribbean }\end{array}$ & 34.0 & 26.5 \\
\hline Asia and the Pacific & 69.7 & 48.9 \\
\hline Central and Eastern Europe & 98.5 & 77.5 \\
\hline North America & 89.2 & 66.7 \\
\hline Western Europe & 41.4 & 30.9 \\
\hline World & 29.5 & 22.0 \\
\hline Groups in terms of degree of country development & 45.7 \\
\hline Developing countries & 63.8 & 71.5 \\
\hline Transition countries & 92.9 & \begin{tabular}{c} 
\\
\hline Developed countries
\end{tabular} \\
\hline
\end{tabular}

Source: ILO, 2014, p. 268.

When observing the values of the indicators of population coverage effective participation of the total number of contributors in the labour force and the working age population by regions, it can be noted that the highest population coverage by pension insurance is in North America, Western Europe and Central and Eastern Europe. In North America, population coverage by pension insurance is double the size in comparison to the average reported in the world and it is somewhat smaller in Western Europe. The lowest population coverage was noted in the Sub-Saharan Africa and Africa. In North Africa and the Middle East, it can be seen that the share of active contributors in the labour force population is double the size of the share of active contributors in the working age population, which means that a great part of the working age population does not comprise the labour force. In terms of coverage, developed countries are dominant according to both indicators, and the smallest difference between these indicators was noted among the developing countries. 
Table 6 Indicators of effective population coverage by pension and disability insurance in EU-27 (in \%)

\begin{tabular}{|c|c|c|c|}
\hline Country & $\begin{array}{c}\text { Share of active } \\
\text { contributors in the } \\
\text { labour force } \\
(15+)\end{array}$ & $\begin{array}{c}\text { Share of active } \\
\text { contributors in the } \\
\text { working age } \\
\text { population } \\
(15-64) \\
\end{array}$ & Year \\
\hline Austria & 87.1 & 66.5 & 2010 \\
\hline Belgium & 94.4 & 64.5 & 2010 \\
\hline Bulgaria & 79.2 & 54.4 & 2009 \\
\hline Czech Rep. & 95.7 & 67.7 & 2010 \\
\hline Cyprus & 77.5 & 58.1 & 2010 \\
\hline Denmark & 96.6 & 78.1 & 2010 \\
\hline Estonia & 82.3 & 63.6 & 2010 \\
\hline Finland & 85.0 & 64.5 & 2010 \\
\hline France & 93.3 & 66.2 & 2010 \\
\hline Germany & 76.8 & 59.9 & 2010 \\
\hline Greece & 92.3 & 64.3 & 2010 \\
\hline Hungary & 100.0 & 71.0 & 2009 \\
\hline Ireland & 100.0 & 77.6 & 2010 \\
\hline Italy & 91.9 & 58.2 & 2010 \\
\hline Latvia & 74.9 & 56.6 & 2010 \\
\hline Lithuania & 76.0 & 54.5 & 2010 \\
\hline Luxembourg & 100.0 & 100.0 & 2010 \\
\hline Malta & 87.2 & 53.5 & 2010 \\
\hline Netherlands & 100.0 & 100.0 & 2010 \\
\hline Poland & 88.8 & 59.1 & 2010 \\
\hline Portugal & 74.5 & 58.6 & 2010 \\
\hline Romania & 54.7 & 37.2 & 2010 \\
\hline Slovakia & 77.1 & 53.2 & 2010 \\
\hline Slovenia & 84.4 & 61.7 & 2011 \\
\hline Spain & 89.0 & 66.0 & 2010 \\
\hline Sweden & 100.0 & 92.8 & 2010 \\
\hline U. Kingdom & 92.9 & 71.4 & 2005 \\
\hline
\end{tabular}

Source: ILO, 2014, pp. 270-271.

In the European Union, the highest coverage by pension insurance was realised by the Netherlands and Luxembourg, which noted full population coverage according to the observed indicators. They are followed by Sweden, Ireland and Hungary, which show full coverage in terms of the share of active contributors in the labour force, and a very high, but not full, in terms of the share of active contributors in the working age population. Besided these countries, high coverage was also noted in Denmark, the Czech Republic, Belgium, France, the United Kingdom, Greece and Italy, where, according to 
the first indicator, it is over $90 \%$, and according to the second it is smaller. The lowest coverage was realised in Romania, Portugal and Latvia. They are followed by Lithuania, Germany, Slovakia and Cyprus. The largest difference among the observed indicators was noted for Italy and Malta, Belgium, Poland and Hungary, and the least for Sweden, Portugal and Germany, whereas the indicators for the Netherlands and Luxembourg were identical.

According to data from 2010, the share of active contributors in the labour force in Serbia was $61.1 \%$, and the share of active contributors in the total working age population was $29.7 \%$ (ILO, 2014, p. 271). In comparison to EU27 members, these values are very unfavourable because a lower value of the first indicator was only noted in Romania, whereas the second indicator was significantly lower than for EU-27 Member States where it is the lowest. Even in Croatia these values are higer, where the share of active contributors in the labour force was $77.3 \%$ in this same year, and the share of active contributors of the total working age population was $50.8 \%$ (ILO, 2014, p. 270). A very low value of these indicators in relation to EU-27, as well as to the former Yugoslav Republics, Croatia and Slovenia, shows that there is high contribution evasion in Serbia and that it is necessary to increase the efficiency of collection and enforcement of contribution for pension and disability insurance.

\section{The Efficiency of Collection and Enforcement of Contribution for Pension and Disability Insurance}

Effective population coverage by pension insurance is always smaller than the legal coverage, since those who by law participate in pension plans do not fulfil their obligations in terms of contribution payment for pension and disability insurance. The reasons for this are numerous and, therefore, it is of great importance to point them out and also the options which are available for the harmonization of the legal and effective coverage. This would enable the decrease of contribution evasion for pension and disability insurance and affect the increase of the pension system revenues.

Contribution evasion occurs when employees and employers do not pay or insufficiently pay contributions (Bailey \& Turner, 2001, p. 385). Employers do this most often by not reporting employees (especially those who have part-time jobs or who have temporary jobs), by not reporting the employees' wages (partially or fully), by postponing contribution payment or remitting contributions funds, and employees do this by working in the informal sector (McGillivrey, 2001, p. 5). Employees in the informal sector are usually those who have low incomes or are self-employed, those who work in very small (unregistered) companies or the household sector, and employees with part-time jobs (employees migrants) in fields, such as agriculture, construction work and services (Hu \& Stewart, 2009, p. 2). 
The reasons for contribution evasion exist both among employers and for the employees (McGillivrey, 2001, pp. 5-6). For employers, they usually occur due to the tendency to reduce the costs of the labour force, complex paperwork upon payment and inadequate evidence in small firms, on the basis of which the value of contribution that needs to be paid is determined. The most common reasons for contribution evasion among the employees are myopia, poverty, distrust of the social system, that is pension insurance, preference of current consumption and calculating pension benefits based on earnings for several years, which precede retirement in the defined benefit pension plans (McGillivrey, 2001, pp. 5-7).

The consequences of contribution evasion for pension and disability insurance are numerous. Contribution evasion significantly reduces the amount of paid contributions in the pension system and threatens its financial sustainability, but it also creates inequality among those who do pay and those who do not pay contributions (ISSA, 2013, p. 7) (Bailey \& Turner, 2001, p. 386). To prevent the negative consequences of the evasion and realise timely and full payment of contributions, it is necessary to efficiently manage the collection and enforcement of contribution for pension and disability insurance. In order to achieve this, it is necessary to:

1. define a system for collection and compliance of contributions,

2. choose an adequate strategy for reducing contribution evasion.

Defining the system for collection and compliance of contributions, that is determining its general and specific activities and processes, is the basis for its efficient functioning. First, general activities are defined, which imply the identification of the system mission, defining goals, choice of strategy which would be used for realizing it (ISSA, 2013, pp. 7-9). Then, specific activities and processes are determined, which are crucial for timely and full payment of contribution for pension and disability insurance. These include (ISSA, 2013, p. 9):

1. registration of the employer, employees, banks and other financial institutions,

2. identifying and determining the employees' and employers' obligations,

3. validation of contribution payment,

4. collection of contributions,

5. recording contributions paid by a contributor over the duration of working life,

6. monitoring compliance and controlling fraud,

7. debt management,

8. enforced collection (which involves court),

9. operational processes which connect all crucial elements and information flows among different parts within an organization.

When all activities and processes are identified, adequate organisation and communication in the system needs to be established, and then continually strive towards increasing efficiency in contribution collection and enforcement, 
in order for the collected contributions to be as large as possible and evasion as little as possible.

For the realisation of efficiency in contribution collection and enforcement for pension and disability insurance, it is equally important to choose a strategy which will enable the reduction of contribution evasion. This can be achieved by choosing a strategy in accordance with the changes, which are necessary for a specific pension system. The choice can be made among the strategies for (Bailey \& Turner, 2001, pp. 387-392):

1. changing the structure of the social insurance system,

2. changing the attitudes of the employees, the employers and the government,

3. administrative changes,

4. changes in the macroeconomic environment.

The first group of strategies implies numerous changes in the system structure itself. This usually concerns reducing the contribution rates, tying benefits to contributions, government subsidies for contribution payment, harmonisation of various programmes for social security, as well as identifying an adequate method for increasing coverage.

Strategies for changing the attitudes of the employees, the employers and the government are directed towards performing various actions which would encourage contribution payment. This can be realised through public and educational campaigns, which emphasize the benefits of paying contributions and point out the penalties for not paying them, publication of the names of the employees and the employers who do not pay contributions in newspapers or on websites, etc.

Reducing contribution evasion by strategies which rely on administrative changes is performed by increasing efficiency of administration (changes in reporting, choice of methods for contribution collection, improving records of contributions, etc.), by incentives for paying contributions (highlighting politicians who do this, granting amnesty, simplifying the laws so that they become more understandable, training the employed who give advice to the employees and the employers, reducing the number of forms that need to be filled out by employers when paying contributions, etc.) and by changes in collection and penalties (focusing on larger employers if there are no financial funds for control, preventing corruption, having adequate penalties for not paying contributions).

The last group of strategies refers to strategies for changes in the macroeconomic environment. They represent a kind of reaction to the changes of this environment and they are undertaken with the aim of reducing negative effects of those changes on the level of collected contributions for pension and disability insurance. An example of these strategies is the situation when there 
is a high level of inflation, unemployment and financial problems among the employees and the employers, which prevent timely and full contribution payment. In order to solve these problems, it is possible, for example, to apply a strategy which temporarily reduces the contribution rate for pension and disability insurance.

Finally, in order to increase the level of contribution for pension and disability insurance, it is important to pay attention to the aims, specifics and needs of each pension system separately, when choosing a strategy for reducing contribution evasion and defining a system for their collection and enforcement.

\section{Conclusion}

After a detailed explanation and analysis of the most important contribution determinants, it has been concluded in which way they can affect the contributions for pension and disability insurance and the options for increasing the levels of these contributions have been identified.

An increase of the contribution levels for pension and disability insurance can be realised by extending the definition of contribution base, as well as by reducing the minimum and increasing the maximum contribution base. Contribution base is defined in a different way in the European Union Member States, so that in accordance with this, the options for increasing contributions in this way differ as well. Through analysis of the definition and regulation about the minimum and maximum monthly contribution base for pension and disability insurance, it has been found that, in Serbia, there are options for extending the definition of contribution base in the category of the employees, whereas it is not possible to reduce the minimum and increase the maximum contribution base.

Affecting the level of contribution through contribution rate can be realised by increasing it, but only to a certain level. Increasing this rate does not always affect increasing the level of contribution of the pension system, but only when this increase is made with considering the economic capacities of the employees and the employers. The contribution rate has increased several times in the previous period in Serbia, so that it now belongs to the group of countries which have a high contribution rate. Having in mind the state of the economy, high unemployment rate and dominant contribution evasion, future increase of this rate is not recommended.

The possibility for increasing contributions for pension and disability insurance by increasing the duration of work life is reflected in later retirement. For the observed period, duration of work life increased in all Member States, except in Romania, which affected the increase of the EU-27 average. Nevertheless, this is still not a sufficient increase in order to realize higher revenues in the pension system. By increasing the average effective retirement age, 
by defining a higher legal retirement age and taking measures for discouraging early retirement, lengthening the duration of work life and the period for contribution payment will be possible, which will positively affect the total contribution level. In countries where options for increasing contributions through contribution base and rate were used, it is recommended to accelerate the dynamics of reaching this legal retirement age and undertaking the necessary measures for increasing the average effective retirement age. This recommendation applies to Serbia, but also to other countries which are in the same situation.

Finally, the possibility of increasing contributions for pension and disability insurance on the basis of increasing population coverage should not be neglected. It can be realised through increasing the effective population coverage by this insurance and its harmonization with the legal population coverage. The effective population coverage by pension and disability insurance in Serbia is significantly lower in comparison to the EU-27 Member States, which indicates the existence of high contribution evasion and the necessity to undertake measures for increasing efficiency in contribution collection and enforcement for pension and disability insurance.

\section{References}

Bailey, C. \& Turner, J. (2001). Strategies to Reduce Contribution Evasion in Social Security Financing. World Development, 29 (2), 385-393.

Cichon, M., Scholz, W., van de Meerendonk, A., Hagemejer, K., Bertranou, F. \& Plamondon, P. (2004). Financing Social Protection: Quantitative Methods in Social Protection Series. Geneva: International Labour Office/International Social Security Association.

Demarco, G. \& Rofman, R. (1999). Collecting and Transferring Pension Contributions. (Social Protection Discussion Paper Series, No. 9907), Washington D.C.: World Bank.

Eurostat, online data code: ifsi_dwl_a, accessed: June 1, 2015.

Fultz, E. \& Stanovnik T. (Eds.) (2004). The Collection of Pension Contributions: Trends, Issues and Problems in Central and Eastern Europe. Budapest: International Labour Office.

Hu, Y. \& Stewart F. (2009). Pension Coverage and Informal Sector Workers: International Experiences (OECD Working Papers on Insurance and Private Pensions, No. 31), Paris: OECD Publishing, retrieved: http://dx.doi.org/10.1787/227432837078, accessed: June 11, 2015.

ILO (2014). World Social Protection Report 2014/15: Building Economic Recovery, Inclusive Development and Social Justice. Geneva: International Labour Office.

ISSA (2013). ISSA Guidelines on Contribution Collection and Compliance. Geneva: International Social Security Association.

McGillivrey, W. (2001). Contribution Evasion: Implications for Social Security Pension Schemes. International Social Security Review, 54 (4), 3-22. 
Nacionalna agencija za lokalni ekonomski razvoj. Sistem oporezivanja rada i mogući pravci njegove reforme, retrieved: http://www.naledserbia.org/upload/CKEditor/Sistem\%20oporezivanja\%20rada\%20i\%20moguci\% 20pravci\%20njegove\%20reforme.pdf, accessed: June 10, 2015.

OECD (2005). Private Pensions: OECD Classification and Glossary. Paris: OECD Publishing, retrieved: http://www.oecd.org/finance/private-pensions/38356329.pdf, accessed: June 5, 2015.

OECD (2013). Pensions at a Glance 2013: OECD and G20 Indicators. Paris: OECD Publishing, retrieved: http://dx.doi.org/10.1787/pension_glance-2013-en, accessed: June 5, 2015.

OECD, retrieved: http://www.oecd.org/els/public-pensions/ageingandemploymentpoliciesstatisticsonaverageeffectiveageofretirement.htm, accessed: June 1, 2015.

Pallares-Miralles, M., Romero, C. \& Whitehouse, E. (2012). International Patterns of Pension Provision II: A Worldwide Overview of Facts and Figures (Social Protection \& Labor Discussion Paper, No. 1211), Washington, D.C.: World Bank.

Petraković, D. (2007). Reforma sistema penzijsko-invalidskog osiguranja u Srbiji. Industrija, 2, 29-46.

Pošarac, A. (1995). Reforma sistema socijalnog i penzijskog osiguranja: nužnost ili modni trend. U: Popović, T. \& Stamenković S. (Ur.), Makroekonomska politika nakon sankcija (str. 73-93). Beograd: Institut ekonomskih nauka.

Rakić, B. \& Nikolić, M. (2011). Uticaj demografskih kretanja na sisteme penzionog osiguranja. U: Aranđelović, Z. (Ur.), Regionalni razvoj i demografski tokovi zemalja Jugoistočne Evrope (str. 403-413). Niš: Ekonomski fakultet.

Rakić, B. \& Ivković, M. (2010). Reform of Pension Systems with Respect to the Reform in Serbia. In: Spasić, D. \& Stanković, Lj. (Eds.), The Challenges of Economic Science and Practice in the 21th Century (pp. 51-63). Niš: Faculty of Economics.

Republički fond za penzijsko i invalidsko osiguranje (2015). Statistički godišnji bilten 2014. Beograd: Republički fond za penzijsko i invalidsko osiguranje.

Republički fond za penzijsko i invalidsko osiguranje, retrieved: http://www.pio.rs/lat/osnovice.html, accessed: June 21, 2015.

SSA \& ISSA (2002). Social Security Programs Throughout the World: Europe, 2002. Washington D.C.: U.S. Government Printing Office.

SSA \& ISSA (2014). Social Security Programs Throughout the World: Europe, 2014. Washington D.C.: U.S. Government Printing Office.

Zakon o doprinosima za obavezno socijalno osiguranje (Službeni glasnik Republike Srbije, 84/2004).

Zakon o izmenama i dopunama Zakona o doprinosima za obavezno socijalno osiguranje (Službeni glasnik Republike Srbije, 62/2006).

Zakon o izmenama i dopunama Zakona o doprinosima za obavezno socijalno osiguranje (Službeni glasnik Republike Srbije, 47/2013).

Zakon o izmenama i dopunama Zakona o doprinosima za obavezno socijalno osiguranje (Službeni glasnik Republike Srbije, 57/2014). 


\section{DETERMINANTE VISINE DOPRINOSA ZA PENZIJSKO I INVALIDSKO OSIGURANJE: EU I SRBIJA}

Apstrakt: U teoriji i praksi, velika se pažnja poklanja analizi visine rashoda za penzije, njihovih determinanti, kao i mogućnostima za njihovo smanjenje, dok se analiza visine prihoda i doprinosa, kao najznačajnijeg prihoda u penzijskim sistemima koji su zasnovani na uplati doprinosa, često zanemaruje. Cilj ovog rada je da se analiziraju determinante visine doprinosa za penzijsko i invalidsko osiguranje radi utvrđivanja mogućnosti za povećanje njihove visine $\mathrm{u}$ penzijskom sistemu Republike Srbije. Primenom metode komparacije, izvršena je uporedna analiza podataka o kretanju najznačajnijih determinanti visine doprinosa između zemalja Evropske unije i Srbije. Rezultati istraživanja pokazali su da se povećanje visine doprinosa za penzijsko i invalidsko osiguranje u Republici Srbiji može ostvariti proširenjem definicije osnovice doprinosa kod zaposlenih, povećanjem prosečne efektivne starosti pri penzionisanju i povećanjem efektivne pokrivenosti stanovništva ovim osiguranjem. Pored ukazivanja na mogućnosti za povećanje visine doprinosa za penzijsko i invalidsko osiguranje, autori predlažu i mere čijom se primenom može uticati na povećanje visine doprinosa za ovo osiguranje, a samim tim, i visine ukupnih prihoda penzijskog sistema Republike Srbije.

Ključne reči: penzijski sistem, penzijsko i invalidsko osiguranje, determinante visine doprinosa, Evropska unija, Srbija

\section{Authors' biographies}

Milena Nikolić was born on January 3rd, 1983 in Niš. She graduated from the Faculty of Economics in Niš in 2007, and she completed her Master studies at this same faculty in 2013. Currently, she is a PhD student at the Faculty of Economics in Niš. She held the position of Account Officer and Cashier Controller in Societe Generale Bank in Niš during the period from 2007 to 2008 and for the school year 2009/2010, she volunteered as an assistant for the course Economics of the Public Sector at the Faculty of Economics in Niš. From 2009 to 2013, she was the scholar of the Ministry of Education, Science and Technological Development of the Republic of Serbia. She has published five co-authored papers and took part in projects of the Faculty of Economics no. 149052 and 179066, funded by the Ministry of Education, Science and Technological Development of the Republic of Serbia.

Biljana Rakić is a professor at the Faculty of Economics in Nis. She earned her master and $\mathrm{PhD}$ degree from the Faculty of Economics in Belgrade. Areas of her scientific interest include Economic Development and Public Economics. She published over 100 scientific papers in international and national journals and participated at numerous international conferences. She got a prestigious scholarship from the U.S. Government and spent 12 months at following institutions: University of Minnesota, University of Pittsburgh, Centre for Russian and East European Studies. During the summer 2004 she volunteered at Economic Department of the Embassy of Serbia in Washington D.C. Professor Rakic is a long-standing member of the American Economic Association. Also, she is a member of many other international and national professional associations: Experts in Public Administration, Education and Public Policy in Countries in Transition, State Department Alumni Association, Fulbright Alumni Association of Serbia, and Scientific Society of Economists of Serbia. She is a member of the Serbian Higher Education Reform Experts Team (HERE) in the current three year mandate. Also, she is a reviewer at CAQA (Commission for Accreditation and Quality Assurance) of the Republic of Serbia. She completed education in the area of the EU Public Policies, at the University of Belgrade European Policy Centre. Fluently speaks English and Russian. 